\title{
Richard C. Bush, At Cross Purposes : U.S.-Taiwan
} Relations Since 1942

Armonk, New York, M.E. Sharpe, 2004, 304 p.

\section{Alan D. Romberg}

\section{OpenEdition}

\section{Journals}

Édition électronique

URL : http://journals.openedition.org/chinaperspectives/506

DOI : 10.4000/chinaperspectives.506

ISSN : 1996-4617

\section{Éditeur}

Centre d'étude français sur la Chine contemporaine

Édition imprimée

Date de publication : 1 août 2005

ISSN : 2070-3449

\section{Référence électronique}

Alan D. Romberg, «Richard C. Bush, At Cross Purposes : U.S.-Taiwan Relations Since 1942 », China

Perspectives [En ligne], 60 | july - august 2005, mis en ligne le 29 novembre 2006, consulté le 21 septembre 2020. URL : http://journals.openedition.org/chinaperspectives/506 ; DOl : https://doi.org/ 10.4000/chinaperspectives.506

Ce document a été généré automatiquement le 21 septembre 2020

(c) All rights reserved 


\section{Richard C. Bush, At Cross Purposes: U.S.-Taiwan Relations Since 1942}

Armonk, New York, M.E. Sharpe, 2004, 304 p.

Alan D. Romberg

1 Richard C. Bush, former Chairman of the American Institute in Taiwan (AIT) and staff member on the House International Relations Committee, has published an extraordinary collection of essays on US-Taiwan relations. In so doing, Bush shares with readers a rare depth of knowledge and insightful policy perspective. While each essay stands on its own, one will miss a great deal by not taking in the entire anthology of highly readable pieces.

2 Bush covers a wide range of topics that include an original exploration of President Franklin D. Roosevelt's wartime decision to return Taiwan to China; the American dilemma in dealing with Kuomintang (KMT) repression starting in the mid-1940s along with a unique look at the interaction between Congress and the Taiwanese-American community in later years on the issue of human and political rights; a nuanced discussion of the twin issues of the status of Taiwan and the status of the Republic of China (ROC); an examination of the "sacred texts" in the US "one China" policy; and some observations on the difficulties of navigating the post-Tiananmen waters in Taiwan policy.

3 One unavoidable drawback is that some essays were drafted as much as eight years ago. A fair amount of new material has been declassified since then, especially on negotiations over the three US-PRC joint communiqués. Even so, Bush's insights are based primarily on a deep probing of the historical record, extensive interviews with direct participants in events he discusses, and his own experience, especially in Congress. These will not change, and he presents fresh material of great value and interest to anyone concerned with US Taiwan policy ${ }^{1}$.

4 Bush's discussion of sovereignty takes us back to the early 1940s. He notes how Roosevelt personally set US policy for both historical and strategic reasons, taking due account of the important role of Madame Chiang Kai-shek. He concludes that Roosevelt made his own decisions independent of the advice he received and largely in the 
context of his vision for the post-war world rather than, as some have argued, from a desire to hold China in the war.

Bush notes that, although the changing circumstances in Taiwan and the region after World War II led the United States to pull back from Roosevelt's vision of returning Taiwan formally to "China", in many other ways American Taiwan policy has been quite consistent. He documents, for example, that General Douglas MacArthur's authorisation to the Chinese Nationalists to accept the Japanese surrender on Taiwan was not authorisation for China to resume sovereignty; some legal act had to follow. Although both Taipei (and later Peking) rejected this position, it remained the view from Washington, as well as London.

Bush argues that consideration of trusteeship for Taiwan in the late 1940s stemmed from the desire to deny Taiwan to the Communists for security reasons, not out of concern to promote popular sovereignty. That said, his detailed and well-documented discussion of American reactions to the "2/28 (1947) Incident" vividly demonstrates the considerable complexity in American thinking, including growing qualms about forcing people in Taiwan to accept not just Communist rule, but also a repressive KMT regime. Although, as Bush notes, American options were actually quite limited, his account is a useful reminder of the post-1947 history that is very much a part of the Taiwan psyche, even if unknown or unremembered by people elsewhere.

7 It is clear that the US decision in late 1949/early 1950 not to become embroiled in the Chinese civil war was coloured by the belief the Communists would take over the island by the end of 1950, and the judgement that stopping it was not worth a conflict with the newly established People's Republic of China. The Korean War six months later changed all that, of course.

Bush is especially effective in documenting both the strategic factors and the relevance of Senator Joseph McCarthy's "Who lost China ?" campaign to the US inability to press the KMT to reform in the 1950s and 1960s. He describes as "realistic" the American circumspection in urging a reformist agenda on the Taipei government, but his frustration at the limited effect of US efforts is plainly evident. In discussing this period as well as later efforts to generate attention to human rights abuses in Taiwan, Bush brings to life the role of individual Taiwanese-and the American response-in the burgeoning of Taiwan independence movements abroad.

9 Bush's chapter on the status of the island of Taiwan, on the one hand, and of the political entity known as the Republic of China, on the other, is especially useful in distinguishing between these two issues. This is not often done. At one point, Bush says that the Truman/Acheson statements of early January 1950 "made clear" US acceptance of Taiwan as a part of China. But the statements he cites could be more accurately read as saying that, although no such legal determination had been made, the United States was not going to get involved in the final stages of the Chinese civil war. Moreover, as Bush observes, with the Korean War under way, Truman's statement of June 27th 1950, once again underscored that the United States did not consider that the island's sovereignty had been determined.

10 A consistent dual theme has run through American Taiwan policy ever since : that the issue should not be resolved through the use of force but neither should the island be turned over to a Communist regime without an effort to determine the will of the people of Taiwan. Of course, by the 1960s and 1970s, a countervailing consideration was the desire-originally-not to foreclose and-later-to foster good US relations with the 
PRC. This included, Bush notes, fashioning a policy that avoided giving the PRC justification or provocation for seizing Taiwan-for example, by backing a legally separate, independent state.

11 Although domestic American political developments after 1952 generated greater support for the ROC's diplomatic status, Bush shows how the United States was concerned then, as later-albeit in quite different circumstances-to avoid a commitment to defend Taiwan against a PRC attack that Taipei had provoked. And by the mid-1950s, people were actively looking for ways to mitigate the danger of crossStrait war. In the ambassadorial "Warsaw Talks" with Peking, Washington sought to achieve this through a mutual renunciation of force. Bush judges that this effort "almost succeeded," but this seems unlikely, as Peking was assiduous in avoiding any such commitment regarding the "internal" affairs of Taiwan.

The US approach in these talks, Bush notes, was pragmatic, treating China as a "divided country," in essence "one China, two governments"-one of which (the ROC) Washington dealt with on a de jure basis, and the other (the PRC) on a de facto basis. Moreover, Bush effectively documents that, contrary to popular notions, John Foster Dulles's objection to PRC UN membership was not ideological but rather grounded in doubts about "its ability to govern China without serious domestic resistance."

Bush speculates that if Chiang Kai-shek had supported "dual representation" of China in the United Nations, Taiwan might still be represented there. Once again, however, there is nothing in the history of PRC approaches to suggest it would have accepted this, or that Peking would not have eventually succeeded in replacing Taipei.

In approaching the US-PRC rapprochement, Bush notes that the United States has been careful not to endorse unification as the ultimate goal (though Dulles did so at one point, he observes, and over the years various presidents have haphazardly endorsed the existence of "one China"). According to his research, the United States has never directly challenged Taipei's claim that the ROC is a "state." But not only did Secretary of State Colin Powell subsequently do so publicly in Peking in October 2004, but rejection of Taipei's statehood claim is fully implicit in the severance of relations with the ROC in 1979 and establishment of diplomatic ties with the PRC, recognising the PRC government as the "sole legal government of China."

Bush is correct in his inference that such recognition did not encompass recognition of the Peking government as the legal government of Taiwan-a fact the PRC occasionally glosses over. But US refusal to support ROC membership in any organisation of sovereign states, and the lack of American diplomatic or official relations with Taipei, as well as Powell's October 2004 statements, all show that, while it generally avoids confronting this issue directly, the United States does not consider the ROC to be a sovereign, independent state.

Bush examines in great detail the "sacred texts" of US China policy and US-PRC relations-the Shanghai Communiqué issued during Nixon's 1972 visit; the Normalisation Communiqué establishing diplomatic relations as of January 1st 1979; and the August 17th 1982 Communiqué, focusing mainly on US arms sales to Taiwan. He observes ruefully that "hardly anyone reads the texts of these documents any more, either fully or carefully." He also notes the importance of ancillary texts and statements to gleaning the full meaning of the "three joint communiqués." 

Washington in October 1997). community. 2005 , this is again a live issue.
Bush helpfully places the relevant portions of various documents side by side, so one can see graphically how any particular issue was handled in each communiqué, whether in the formal text, in a side statement, or in some other way. He notes how "sticky" issues were divided between communiqué text and ancillary statements (much as sensitive Taiwan issues were handled during the state visit of Jiang Zemin to

Bush believes the United States yielded too much to Peking in the various communiqués, especially regarding peaceful resolution of the Taiwan issue. But with the advantage we now have of access to much of the actual negotiating record (an advantage Bush lacked when he was writing), it is clear that at the time of normalisation, while willing to avoid public confrontation, the U.S. was unambiguous in insisting that Peking forego the use of force against Taiwan.

Taking full advantage of his congressional expertise, Bush makes a persuasive case that the extensive textual changes Congress made in spring 1979 to the draft Taiwan Relations Act (TRA), while rhetorically robust, were not as substantively meaningful as is often argued, and that much TRA language falls short of constituting an obligation. Bush's fine-grained discussion of security aspects of the TRA is an invaluable guide to understanding what is policy, what is a commitment, and what is an expression of concern-and, of critical importance, what processes are required before acting.

Bush notes the PRC fixation on US statements in the three joint communiqués to the virtual exclusion of other documents and statements. But this is understandable, because they are the only negotiated statements between the two governments on these matters, and other statements or even documents (e.g., presidential letters) can be rejected not only by the next administration but even by the one that issued them.

In his examination of how the United States treated human rights violations in Taiwan in later years, mainly in the 1980s, Bush again draws deeply on extensive interviews and on his congressional experience, including his exposure to the TaiwaneseAmerican community and the interaction between that community and Members. His presentation is truly a tour de force that does not pull any punches in describing the role of politics and financial contributions to Congress from the Taiwanese-American

In his final chapter, covering policymaking since Tiananmen, Bush observes that Peking rejects yi zhong, ge biao (one China, respective interpretations) as a basis for cross-Strait dialogue. The PRC has previously turned away from that formulation on the grounds that Taiwan's former president, Lee Teng-hui, twisted the original point that both sides held in common the view that there was "one china" and reunification was the ultimate goal, instead promoting "two Chinas" or "one China, one Taiwan." There are signs, however, that, were a Taiwan leader to accept "one China," there need not be agreement on the definition in order to resume dialogue-and perhaps achieve a great deal more-and that yi zhong, ge biao would indeed be an acceptable approach. Given KMT Chairman Lien Chan's embrace of that position while in Peking in April

23 Bush also reminds us that creating a political framework for managing cross-Strait relations short of unification, under discussion these days, is not a new idea; it was very much part of the US position in the mid-1990s. The problem then, as now, was that such a framework was elusive in light of the increasingly conflicting goals of the two 
sides. Although both wanted to avoid confrontation and war, neither was willing to commit formally to such restraint because it seemed to encompass too great a sacrifice of "principle."

Bush raises the critical point that, while it is theoretically possible to imagine a longterm resolution unrelated to some concept of "one China," in fact this seems highly unrealistic. Moreover, he suggests there are certain concepts of "one China" that would not only preserve full autonomy for Taiwan but that could also incorporate aspects of true sovereignty.

While that is not possible under current circumstances, if Peking truly wants peaceful reunification, it has a strong incentive to think more creatively about its own definition of "one China"-eventually moving away from the "one country, two systems" concept, which is unacceptable in Taiwan precisely because it presumes a single, unified sovereignty under the aegis of a government in Peking. The PRC's omission of "one country, two systems" from the March 2005 "Anti-Secession Law" may be a sign that Peking is beginning to consider how to square its own bottom line on "one China" with Taiwan's on self-determination.

The PRC's goal of formal reunification is obviously a long-term one, unrealisable within decades if not longer. The more pertinent task for the medium term-the timeframe that is relevant to policymaking in all three capitals-is how to avoid crises and promote positive relations.

To succeed in that task, it is necessary to have a clear understanding of how we got where we are. Richard Bush's book goes a long way to helping us gain that understanding.

\section{NOTES}

1. If Bush produces a second edition, one hopes he might rethink his decision to use the PRC's pinyin romanisation system even for Taiwan figures, who do not use that system. 